\title{
構造体コンクリートから採取したコア供試体の \\ 圧縮強度レベルと確率分布形状 \\ PROBABILITY DISTRIBUTION CORESPONDING TO \\ COMPRESSIVE STRENGTH OF CONCRETE CORE SPECIMENS IN STRUCTURES
}

\author{
鈴木 澄汇*，栘田佳寛**，佐藤幸惠*** \\ Sumie SUZUKI, Yoshihiro MASUDA and Sachie SATO
}

\begin{abstract}
The probability distribution of compressive strength class of any kinds of concrete was definied as normal distribution in quality control even in structure concrete. It is clear that the peak of distribution is higher than the mean value of strength in high strength concrete, nevertheless the mean value is equal to the peak of distribution in ordinary strength class of concrete. In this report, it was clarified that the shape of probability distribution of compressive strength of core specimens in high strength concrete structures was not normal distribution. So, if the probabilistic property of concrete strength is assumed to follow a normal distribution in quality control, it makes the strength lower than the design strength in structure concrete.
\end{abstract}

Keywords: Strength of concrete in structure, Compressive Strength, Shape of probability distribution. Normal probability distribution 構造体コンクリートの強度, 压縮強度, 確率分布形状, 正規分布

1. はじめに

日本建築学会の建築工事標準仕様書・同解説 JASS5鉄筋コンクリ 一ト工事 (以下 JASS5 と略す)に定めら扎いるコンクリートの品質 管理の方法は、コンクリートの圧縮強度の分布は強度レベルにかか わらず正規分布であるとみなして、不良率に対する正規偏差を 1.73 としている”。筆者らは、前報”で管埋用供試体におけるコンクリ 一トの強度レベルと確率分布形状の関係を検討し、コンクリートが 高強度化するとその確率分布形状は正規分布を示さず、最大頻数が 最大值側に移行し、また、下限值側の分布のすそが広がる傾向を示 すことを解析し、報告した。本研究では、設計基準強度 $36 \mathrm{~N} / \mathrm{mm}^{2}$ 以 上のコンクリートを用いて実施された実大施工実験において構造体 コンクリートから採取したコア供試体の圧縮強度を対象として、そ の強度レベルと確率分布形状について解析し、分布の特性と品質管 理上の問題点について検討を行った。

\section{2. 対象とした資料の概要}

本論文では、日本建築センターの高層鉄筋コンクリート造技術指 導委員会（旧技術検討委員会）で1986年以降に実施された46件の技
術指導（技術検討）のうち、実大施工実験の報告書で構造体から採 取した個々のコア供試体の压縮強度、調合条件、採取位置等の諸元 がそろっている41件の報告書"、建設省総合技術開発プロジェクト 「鉄筋コンクリート造建築物の超軽量・超高層化技術の開発」（略 称、NewRC 総プロ）の実大施工実験の報告書 ${ }^{32}$ および筆者らが関 係した 80〜 100 N/mm? 級高強度コンクリートの実大施工実験の結果 "〜" を検討対象とした。対象とした実験の諸元を表一 1 に示す。 検討対象としたコンクリートの水セメント比の範囲は、19.0\%〜 5 2. $5 \%$ (圧縮強度の平均値の範囲は $31.4 \mathrm{~N} / \mathrm{mm}^{2} \sim 119.3 \mathrm{~N} / \mathrm{mm}^{2}$ ) であ る。コンクリートに用いられた結合材の種類は、圧縮強度の平均值 が $70 \mathrm{~N} / \mathrm{mm}^{2}$ 末満（強度レベルの区分 $60 \mathrm{~N} / \mathrm{mm}^{2}$ ）までは普通ポルトラ ンドセメントであり、そ狄以上の強度レベルのものは、普通ボルト ランドセメント、低熱ポルトランドセメント（ハイフローセメン ト）およびセメントの‥部を混和材で置換したもの（エトリンガイ 卜系混和材、シリカフューム等) である。コア供試体の圧縮強度試 験結果を解析するにあたり、強度レベルを表一 2 に示す 4 つの区分 に分け、1 部材から採取したコア供試体（1 部材から採取したコア 供試体の数 $\mathrm{N}=2 \sim 44 ）$ の圧縮強度の平均值でふり分けた。なお、

\footnotetext{
* 財列材試験センター中央試験所材料グルーブ 専門職 (宇都宮大学大学院上学研究科博士後期昩程 生应・情報工学専攻大学院生)

** 宇都宮大学:上学:部建設学科教授・上博

*** 宇都宮大学丁学部建設学科 研究員. 丁. 博
}

Expert Official, Materials Testing Group, Central Laboratory, Japan Testing Center for Construction Materials

(Graduate Student, Department of Production and Information Science, Doctor's Degree Course, Graduate School of Engineering, Utsunomiya Univ.)

Prof., Dept. of Architecture and Civil Engineering, Faculty of Engineering, Utsunomiya Univ., Dr. Eng.

Research Engineer, Dept. of Architecture and Civil Engineering, Faculty of Engineering, Utsunomiya Univ., Dr. Eng. 
表-1 高強度コンクリート実大柱部施エ実験概要

\begin{tabular}{|c|c|c|c|c|c|c|c|c|c|c|c|}
\hline \multirow[b]{2}{*}{ 番号 } & \multirow[b]{2}{*}{$\begin{array}{l}\text { 施工実験 } \\
\text { 実施時期 }\end{array}$} & \multirow[b]{2}{*}{ 実験場所 } & \multirow[b]{2}{*}{ 部材数 } & \multicolumn{4}{|c|}{ 材齢28日 } & \multicolumn{4}{|c|}{ 材楼令91日 } \\
\hline & & & & $\begin{array}{l}\text { 供試体数 } \\
\text { (N) の範囲 }\end{array}$ & $\begin{array}{c}\text { 圧縮強度の } \\
\text { 平均値の範囲 } \\
\left(\mathrm{N} / \mathrm{mm}^{2}\right)\end{array}$ & $\begin{array}{c}\text { 標準偏差 } \\
\text { の範囲 } \\
\left(\mathrm{N} / \mathrm{mm}^{2}\right)\end{array}$ & $\begin{array}{c}\text { 変動係数 } \\
\text { の範囲 } \\
(\%)\end{array}$ & $\begin{array}{l}\text { 供試体数 } \\
\text { (N)の範囲 }\end{array}$ & $\begin{array}{c}\text { 压縮強度の } \\
\text { 平均值の範囲 } \\
\left(\mathrm{N} / \mathrm{mm}^{2}\right)\end{array}$ & $\left|\begin{array}{c}\text { 標準偏差 } \\
\text { の範囲 } \\
\left(\mathrm{N} / \mathrm{mm}^{2}\right)\end{array}\right|$ & $\begin{array}{c}\text { 変動係数 } \\
\text { の範囲 } \\
(\%)\end{array}$ \\
\hline 1 & $\begin{array}{l}1986.4 \sim 1986.5 \\
\end{array}$ & 神奈川県大和市 & 4 & $6 \sim 18$ & $37.8 \sim 47.4$ & $1.52 \sim 4.06$ & $4.0 \sim 8.6$ & $\begin{array}{l}- \\
-\end{array}$ & - & - & - \\
\hline 2 & $\begin{array}{l}1986.4 \sim 1986.5 \\
\end{array}$ & 愛知県豊川市/横浜市 & 4 & $5 \sim 27$ & $42.8 \sim 47.2$ & $1.38 \sim 3.02$ & $3.0 \sim 6.4$ & 27 & $51.1 \sim 52.1$ & \begin{tabular}{|l|}
$2.23 \sim 2.97$ \\
\end{tabular} & $4.4 \sim 5.7$ \\
\hline 3 & 1986.9 & 横浜市 & 4 & 6 & $39.2 \sim 45.2$ & $1.86 \sim 5.98$ & $4.5 \sim 13.6$ & $\begin{array}{ll}- \\
-\end{array}$ & - & - & $=$ \\
\hline 4 & $1986.1 \sim 1986.9$ & 干葉県流山市 & 5 & $6 \sim 18$ & $53.1 \sim 65.1$ & \begin{tabular}{|l|}
$2.46 \sim 4.62$ \\
\end{tabular} & $4.0 \sim 8.7$ & 9 & $77.3 \sim 86.6$ & $2.80 \sim 3.80$ & $3.6 \sim 4.4$ \\
\hline 5 & 1987.2 & 埼玉県与野市 & 3 & 18 & $50.4 \sim 56.3$ & \begin{tabular}{|l|}
$2.83 \sim 5.43$ \\
\end{tabular} & $5.0 \sim 10.8$ & 18 & $58.5 \sim 65.1$ & $3.28 \sim 4.39$ & $5.1 \sim 7.5$ \\
\hline 6 & $\begin{array}{l}1987.1 \sim 1987.9 \\
\end{array}$ & 千葉県東葛飾郡関宿㽗 & 6 & $6 \sim 20$ & $38.9 \sim 47.4$ & $1.88 \sim 3.19$ & $4.7 \sim 7.1$ & $\begin{array}{l}- \\
\end{array}$ & - & - & - \\
\hline 7 & \begin{tabular}{|l|l}
$1986.4 \sim 1987.10$ \\
\end{tabular} & 東京都青梅市 & 11 & $5 \sim 10$ & $40.4 \sim 53.2$ & $0.84 \sim 4.24$ & $2.1 \sim 9.4$ & $\begin{array}{ll}- \\
\end{array}$ & - & - & $\begin{array}{l}- \\
\end{array}$ \\
\hline 8 & $\begin{array}{l}1987.4 \sim 1987.12 \\
\end{array}$ & 神奈川県厚木市 & 8 & $6 \sim 9$ & $46.8 \sim 54.6$ & $1.72 \sim 5.09$ & $3.2 \sim 9.4$ & $3 \sim 9$ & $53.3 \sim 63.8$ & $1.11 \sim 7.72$ & $1.8 \sim 12.9$ \\
\hline 9 & $1987.11 \sim 1988.3$ & 茨城県取手市 & 8 & $8 \sim 25$ & $40.8 \sim 50.1$ & $2.29 \sim 5.44$ & $4.7 \sim 12.5$ & - & - & - & - \\
\hline 10 & $1987.12 \sim 1988.4$ & 神奈川県愛甲郡愛川町 & 3 & $4 \sim 16$ & $51.3 \sim 52.8$ & $1.45 \sim 2.74$ & $2.8 \sim 5.2$ & - & - & $\overline{-}$ & - \\
\hline 11 & $\begin{array}{l}1988.8 \sim 1988.11 \\
\end{array}$ & 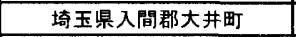 & 5 & $6 \sim 27$ & $44.9 \sim 52.6$ & $2.12 \sim 5.48$ & $\begin{array}{l}4.2 \sim 10.4 \\
\end{array}$ & - & - & - & - \\
\hline 12 & $1988.12 \sim 1989.9$ & 茨城県古河市 & 3 & 18 & $43.5 \sim 46.1$ & \begin{tabular}{|l|}
$1.70 \sim 2.84$ \\
\end{tabular} & $3.9 \sim 6.2$ & 9 & 50.8 & 4.02 & 7.9 \\
\hline 13 & 1989.9 & 千葉県印旌郡白井町 & 3 & $18 \sim 27$ & $49.6 \sim 54.8$ & $1.76 \sim 2.57$ & $3.5 \sim 5.0$ & - & - & - & - \\
\hline 14 & 1989.9 & 大阪市 & 2 & 12 & $49.7 \sim 51.8$ & $3.60 \sim 5.15$ & $6.9 \sim 7.6$ & $\begin{array}{lll}- & & \\
\end{array}$ & $\begin{array}{llll}- & & & \\
\end{array}$ & - & $\begin{array}{lll}- & & \\
\end{array}$ \\
\hline 15 & 1989.11. & 東京都 & 4 & 20 & $62.8 \sim 86.7$ & $4.07 \sim 5.81$ & $6.0 \sim 8.0$ & $16 \sim 17$ & $4.9 \sim 85.3$ & $3.17 \sim 4.78$ & $4.6 \sim 6.0$ \\
\hline 16 & $1988.11 \sim 1990.2$ & 埼玉県南埼玉郡白岡町 & 14 & $2 \sim 14$ & $41.9 \sim 51.6$ & $0.87 \sim 5.49$ & $2.0 \sim 12.3$ & - & - & - & - \\
\hline 17 & \begin{tabular}{|l|}
$1989.9 \sim 1990.7$ \\
\end{tabular} & 兵庫県西宮市 & 8 & $8 \sim 10$ & $48.0 \sim 59.5$ & $3.02 \sim 5.14$ & $5.7 \sim 10.7$ & 10 & $56.6 \sim 64.3$ & $3.20 \sim 5.50$ & $5.0 \sim 9.7$ \\
\hline 18 & $1988.9 \sim 1991.1$ & 干葉県市川市 & 16 & $3 \sim 12$ & $46.1 \sim 64.1$ & $1.35 \sim 7.61$ & $2.6 \sim 12.7$ & $3 \sim 12$ & $499.5 \sim 76.5$ & $\mid 0.29 \sim 6.58$ & $0.4 \sim 11.0$ \\
\hline 19 & $\begin{array}{l}1989.12 \sim 1991.3 \\
\end{array}$ & 五県入間郡日高町 & 9 & $3 \sim 28$ & $36.2 \sim 49.3$ & $2.66 \sim 6.87$ & $6.5 \sim 18.6$ & $8 \sim 18$ & $42.0 \sim 53.0$ & $3.97 \sim 8.30$ & $9.0 \sim 19.8$ \\
\hline 20 & $1990.7 \sim 1991.3$ & 千葉県成田市 & 6 & $15 \sim 26$ & $44.1 \sim 57.3$ & $3.14 \sim 4.32$ & $6.1 \sim 8.2$ & - & - & - & - \\
\hline 21 & $\begin{array}{l}1989.12 \sim 1991.7 \\
\end{array}$ & 茨城県猿島郡総和町 & 16 & $7 \sim 14$ & $38.5 \sim 58.9$ & \begin{tabular}{|l|}
$2.23 \sim 5.29$ \\
\end{tabular} & $3.8 \sim 12.5$ & $3 \sim 9$ & $44.5 \sim 60.7$ & $1.14 \sim 8.55$ & $2.1 \sim 15.7$ \\
\hline 22 & 1991.10. & 茨城県つくば市 & 13 & $9 \sim 18$ & $61.9 \sim 107.0$ & $2.79 \sim 14.61$ & $3.7 \sim 14.1$ & $8 \sim 9$ & $65.5 \sim 108.3$ & \begin{tabular}{|l|}
$2.57 \sim 9.32$ \\
\end{tabular} & $3.5 \sim 8.7$ \\
\hline 23 & 1991.12 & 木県河内郡南河内町 & 3 & 10 & 50.5 & 2.93 & 5.8 & $8 \sim 20$ & $71.6 \sim 74.5$ & $4.16 \sim 4.77$ & $5.6 \sim 7.9$ \\
\hline 24 & $1991.1 \sim 1992.1$ & 大阪府門真市 & 15 & $10 \sim 12$ & $37.5 \sim 62.0$ & $2.62 \sim 5.78$ & $4.4 \sim 13.7$ & - & - & - & $\begin{array}{c}- \\
-\end{array}$ \\
\hline 25 & \begin{tabular}{|l}
$1991.8 \sim 1992.3$ \\
\end{tabular} & 神奈川県厚木市 & 5 & $10 \sim 18$ & $43.8 \sim 55.6$ & $1.19 \sim 3.53$ & $2.6 \sim 8.1$ & $10 \sim 18$ & $49.3 \sim 64.2$ & $1.54 \sim 5.68$ & $2.8 \sim 11.5$ \\
\hline 26 & \begin{tabular}{|l|}
$1990.9 \sim 1992.11$ \\
\end{tabular} & 干葉県東葛飾郡関宿町 & 11 & $9 \sim 30$ & $45.7 \sim 67.9$ & $1.18 \sim 7.83$ & $1.9 \sim 13.8$ & $9 \sim 15$ & $54.5 \sim 72.9$ & $2.64 \sim 8.20$ & $3.6 \sim 15.0$ \\
\hline 27 & 1993.3 & 東京都府中市 & 4 & 18 & $57.4 \sim 63.0$ & $2.03 \sim 4.87$ & $3.3 \sim 8.1$ & 18 & $69.0 \sim 73.5$ & $1.90 \sim 4.07$ & $2.7 \sim 5.5$ \\
\hline 28 & $1992.6 \sim 1993.3$ & 新潟県育海町 & 6 & 10 & $70.8 \sim 110.7$ & $2.07 \sim 7.79$ & $2.2 \sim 9.3$ & 10 & $80.6 \sim 119.3$ & $\mid 2.16 \sim 6.54$ & $2.1 \sim 6.0$ \\
\hline 29 & $1992.6 \sim 1993.6$ & 干葉県印箅郡印西町 & 8 & $8 \sim 24$ & $47.5 \sim 58.7$ & $2.31 \sim 5.51$ & $4.0 \sim 11.0$ & 8 & $59.7 \sim 65.9$ & $3.48 \sim 5.19$ & $5.6 \sim 8.1$ \\
\hline 30 & $1991.9 \sim 1993.8$ & 埼玉県大宮市 & 15 & $3 \sim 19$ & $42.4 \sim 63.2$ & $0.80 \sim 5.05$ & $1.6 \sim 15.9$ & $3 \sim 19$ & $49.5 \sim 66.7$ & $\mid 1.06 \sim 4.91$ & $1.8 \sim 9.9$ \\
\hline 31 & $1992.1 \sim 1993.8$ & 干葉県富津市 & 11 & $6 \sim 10$ & $50.8 \sim 62.6$ & $1.75 \sim 3.27$ & $3.4 \sim 5.5$ & $2 \sim 14$ & $54.1 \sim 73.1$ & $\mid 0.99 \sim 4.53$ & $1.8 \sim 6.9$ \\
\hline 32 & \begin{tabular}{|l}
$1993.2 \sim 1994.2$ \\
\end{tabular} & 横浜市 & 22 & $6 \sim 18$ & $32.7 \sim 63.9$ & $0.98 \sim 4.89$ & $1.8 \sim 14.8$ & $4 \sim 18$ & $35.6 \sim 68.1$ & $1.45 \sim 6.49$ & $2.4 \sim 12.9$ \\
\hline 33 & \begin{tabular}{|l}
$1993.10 \sim 1994.4$ \\
\end{tabular} & 神奈川県相模原市 & 3 & 12 & $61.5 \sim 74.2$ & $2.39 \sim 7.35$ & $3.2 \sim 11.4$ & 12 & $67.0 \sim 77.5$ & $\mid 2.76 \sim 6.87$ & $4.1 \sim 10.1$ \\
\hline 34 & 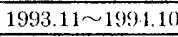 & 千葉県船橋市 & 3 & $1: 4 \sim 16$ & $43.2 \sim 59.4$ & $2.93 \sim 3.45$ & $4.9 \sim 7.4$ & $14 \sim 16$ & $48.0 \sim 64.5$ & $3.54 \sim 4.86$ & $6.4 \sim 8.7$ \\
\hline 35 & 1994.10. & 東京都世田谷区 & 1 & $\begin{array}{llll}- & \\
\end{array}$ & - & - & - & 21 & 53.8 & 4.78 & 8.9 \\
\hline 36 & \begin{tabular}{|l|l}
$1994.6 \sim 1994.11$ \\
\end{tabular} & 干葉県印旗郡印西町 & 8 & $8 \sim 24$ & $\begin{array}{l}45.3 \sim 50.6 \\
\end{array}$ & $1.88 \sim 5.53$ & $4.2 \sim 11.0$ & $7 \sim 22$ & $53.1 \sim 60.1$ & $1.87 \sim 6.26$ & $3.4 \sim 10.7$ \\
\hline 37 & 1994.11 & 千藮県習志野市 & 2 & 17 & 54.8 & 2.46 & 4.5 & 18 & 60.8 & 3.35 & 5.5 \\
\hline 38 & $1993.12 \sim 1994.12$ & 埼玉県上尾市 & 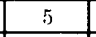 & 9 & $53.4 \sim 59.1$ & $2.11 \sim 2.69$ & $2.4 \sim 5.0$ & $8 \sim 18$ & $55.3 \sim 59.4$ & \begin{tabular}{|l|}
$2.47 \sim 4.17$ \\
\end{tabular} & $4.5 \sim 7.0$ \\
\hline 39 & \begin{tabular}{|c|}
$1993.9 \sim 1995.7$ \\
\end{tabular} & 千葉県市原市 & 15 & $11 \sim 42$ & $40.0 \sim 51.4$ & $1.18 \sim 4.47$ & $2.3 \sim 10.5$ & $11 \sim 42$ & $41.4 \sim 61.0$ & $1.57 \sim 7.18$ & $2.7 \sim 17.3$ \\
\hline 40 & \begin{tabular}{|l|}
$1994.8 \sim 1995.10$ \\
\end{tabular} & 茨城県稲教郡美浦村 & 10 & $8 \sim 20$ & $46.1 \sim 76.1$ & $1.31 \sim 4.28$ & $2.8 \sim 9.0$ & $8 \sim 44$ & $52.3 \sim 78.7$ & $1.76 \sim 5.38$ & $3.0 \sim 8.8$ \\
\hline 41 & \begin{tabular}{|l}
$1990.8 \sim 1995.12$ \\
\end{tabular} & 大阪府茨木市/東京都東大和芇 & 12 & $3 \sim 12$ & $35.8 \sim 65.0$ & $1.74 \sim 4.63$ & $3.3 \sim 9.2$ & $6 \sim 12$ & $39.4 \sim 62.7$ & $1.47 \sim 4.94$ & $3.7 \sim 10.2$ \\
\hline 42 & \begin{tabular}{|l}
$1994.10 \sim 1996.5$ \\
\end{tabular} & 兵庫県三田市 & 14 & $10 \sim 18$ & $31.4 \sim 60.3$ & $2.83 \sim 7.50$ & $5.4 \sim 19.6$ & $9 \sim 18$ & $40.2 \sim 63.2$ & $1.73 \sim 7.39$ & $3.1 \sim 12.5$ \\
\hline 43 & \begin{tabular}{|l}
$1996.6 \sim 1996.12$ \\
\end{tabular} & 東京都八王子市 & 10 & $6 \sim 23$ & $64.0 \sim 83.3$ & $2.94 \sim 9.76$ & $3.8 \sim 13.0$ & $6 \sim 25$ & $77.1 \sim 98.3$ & $1.45 \sim 6.31$ & $1.6 \sim 8.2$ \\
\hline 44 & 1997.5. & 山形県上山町 & 3 & - & - & - & - & $5 \sim 18$ & $111.6 \sim 112.8$ & $3.97 \sim 4.36$ & $3.6 \sim 3.9$ \\
\hline 45 & $\begin{array}{l}997.4 \sim 1998.1 \\
\end{array}$ & 大阪府大東市 & 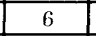 & $2 \sim 6$ & $69.4 \sim 79.1$ & $0.85 \sim 3.35$ & $1.1 \sim 6.3$ & $3 \sim 8$ & $70.7 \sim 81.3$ & $2.69 \sim 7.17$ & $3.6 \sim 8.9$ \\
\hline 46 & 1998.10. & 茨城県つくば市 & 3 & 28 & 109.9 & 5.31 & 4.8 & $10 \sim 26$ & $114.0 \sim 116.5$ & $4.02 \sim 6.22$ & $3.5 \sim 5.3$ \\
\hline 47 & \begin{tabular}{|l|}
$1998.4 \sim 1999.3$ \\
\end{tabular} & 千葉県印旛郡白井町 & 6 & $3 \sim 21$ & $39.9 \sim 57.5$ & $1.46 \sim 3.55$ & $2.8 \sim 7.3$ & $5 \sim 21$ & $51.4 \sim 65.7$ & $0.86 \sim 5.36$ & $1.4 \sim 9.0$ \\
\hline
\end{tabular}

\section{表-2 圧縮強度の区分}

\begin{tabular}{|c|c|c|c|}
\hline 強度レベルの区分 & 圧縮強度の平均值 & \multicolumn{2}{|c|}{ データの個数(個) } \\
\cline { 3 - 4 }$\left(\mathrm{N} / \mathrm{mm}^{2}\right)$ & の範囲 $\left(\mathrm{N} / \mathrm{mm}^{2}\right)$ & 材画令28日 & 材齢91日 \\
\hline 40 & 30以上50末満 & 1989 & 519 \\
60 & 50以上70末満 & 1860 & 1676 \\
80 & 70以上90未満 & 254 & 404 \\
100 & 90以上 & 101 & 191 \\
\hline
\end{tabular}

対象としたコア供試体は、採取高さ、構造体断面での位置での影響 が比較的小さいことが示されているデー夕礼であるので、解析にお いてはそ扎の影響を考虑しないものとした。試駼材齢は材噛28日 及び91日の 2 種類とした。コア供試体の圧縮強度試験結果は、各部 材ごとに求めた圧縮強度の平均值（ $\mathrm{N}=2 \sim 44 ）$ と個々のコア供試体 の圧縮強度について、平均値からの偏差 $(\Delta \mathrm{X})$ と偏差を標本標準
偏差で除した比（V１）を各材粫ごとに求め、それらの分布により 各圧縮強度レベルにおけるバラツキの傾向を確認した。なお、偏差 $(\Delta \mathrm{X})$ 及び偏差を標本標準偏差で除した比（V 1）の求め方の詳 細は、前報”で記述した。

\section{3. 検討結果と考察}

\section{1 圧縮強度レベルと偏差 $\Delta x$ 関係}

図ー 1 に各強度レベルにおける平均値からの偏差（ $\Delta \mathrm{X} ）$ の分 布を示す。強度レベルが $60 \mathrm{~N} / \mathrm{mm}^{2}$ までは、コア供試体の材秢にかか わらず、平均值からの偏差は正規分布を示している。こ扎対し て、強度レベルが $60 \mathrm{~N} / \mathrm{mm}^{2}$ を超える領域になると平均値からの偏差 の分布はその最頻值が強度の高い（+側）方へ移行し、なおかつ最 低強度の分布のすそのが広がる形状を示しており、また、偏差全体 

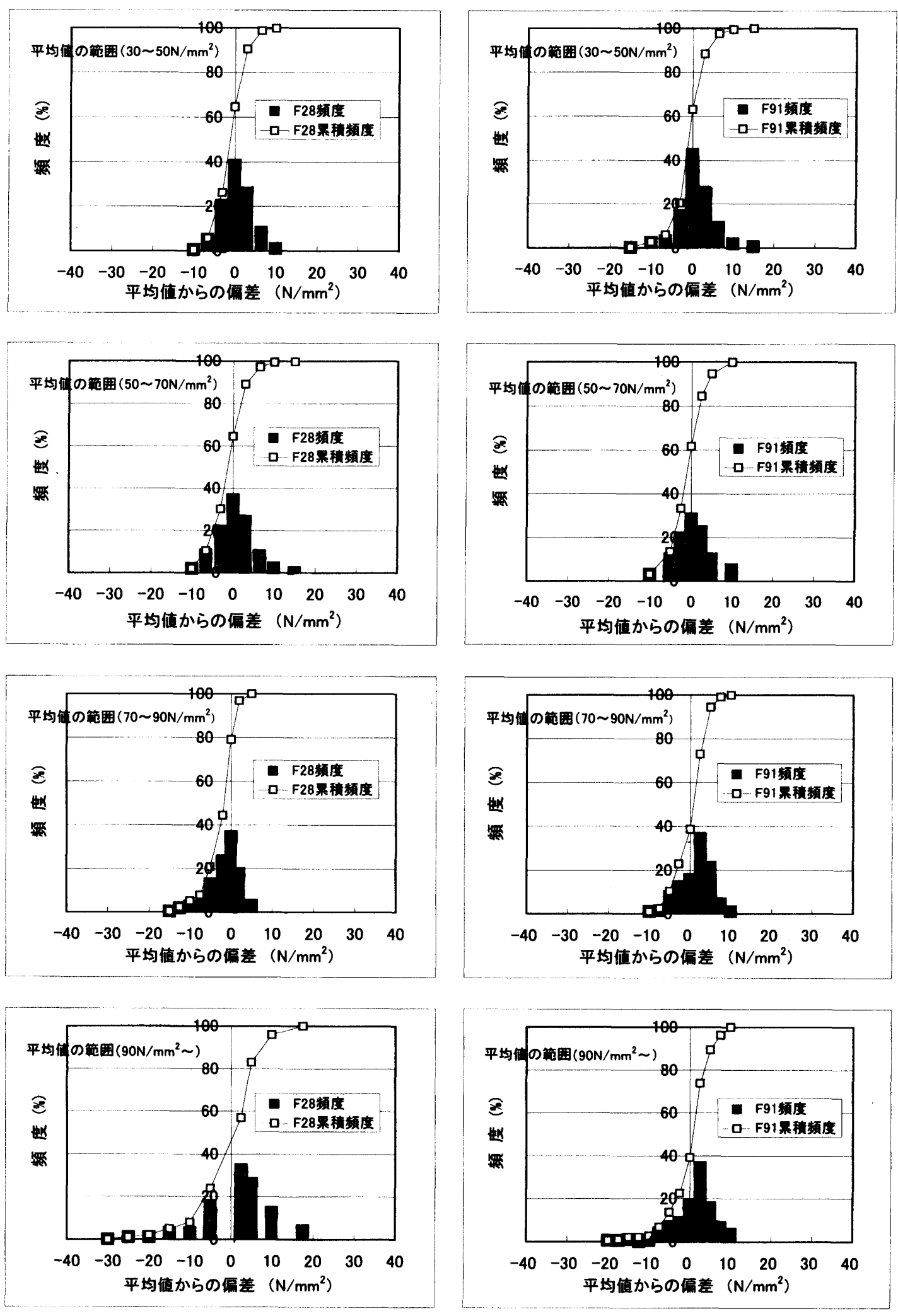

図ー1 コア供試体の圧縮强度(材秢28日及び91日)の平均値からの偏差の分布

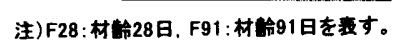


の分布の幅も強度レベルが高くなるほど㕕がる候向を示した。構造 体コンクリートから採取したコア供試体について解析した結果にお いても、前報"で記述した管理用供試体（鋼製型枠を用いて作製し た供試体）とほぼ同様の倾们を示す結果となった。

材齢とコア供試体の厈維強度試験結果の分布を詳細に見ると、強

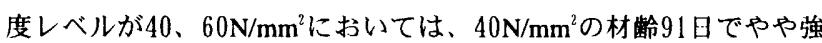
度が离い領域に頻度が多い倾向があるが、いずれもほほ正規分布を 形成していることが確認された。強度レベルが $80 \mathrm{~N} / \mathrm{mm}^{2}$ では、最頻 値が強度の高い領域に移行し、分布のすそのが広がる形状となって

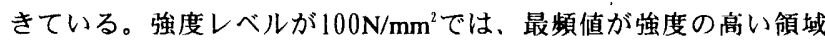
に移行し、最低強度の分布のすそのが広がる倾问がより鮮明に認め られた。これらの結果から、強度レベルが高くなると、その分布形 状は正規分布を示さない叮能性があることが確認された。また、強 度レベルが帛くなることにより、分布の幅が公がる形状を示してお り、これは平均值よりも圧繀強度が低い侧にバラッキが人きくなる ことを示唆するものといえる。

また、個々の施に者別のデータについて解析したところ、強度レ

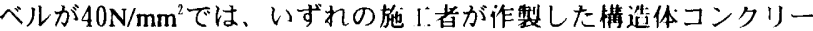
トから採取したコア供試体もその王秎强度の分布形状はほほ正規分 布を示しているが、強度レベルが $60 \mathrm{~N} / \mathrm{mm}^{2}$ 以!では、施、者により その分布が買なる倾向が認められた。図ー2に強度レベルが 60 $\mathrm{N} / \mathrm{mm}^{2}$ (瓜縮強度の平均值 $50 \sim 70 \mathrm{~N} / \mathrm{mm}^{2}$ ) の材踰28[1および91日の 施工者別の㣂差 $(\Delta \mathrm{X})$ の分布の一例を示す。施！者 $\mathrm{A}$ 社は、い ずれの材龄に㧍いても最頻値が平均値よりも帛い側（+侧）に位置 して抢り、かつ、分布形状は正規分布となっていない。また、最低 強度の分布のすそのが人きく公がる形状を示すものとなっている。 一分、施工者 $\mathrm{B}$ 社は、 $\Delta \mathrm{X}$ の分布がほほ平均值を中心に正䙺分布 を示しており、闵ー 1 に示した強度レベルが $60 \mathrm{~N} / \mathrm{mm}^{2}$ までの分布と

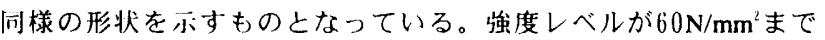
は、多くの施 I者が施に者 $\mathrm{B}$ 社のタイプの分布を示している。し
かし、強度レベルが $80 \mathrm{~N} / \mathrm{mm}^{2}$ あるいは $100 \mathrm{~N} / \mathrm{mm}^{2}$ になると施工者 $\mathrm{A}$ 社の偏差の分布傾向へと移行する特徵が認められた。これらの傾向 が異なる原因としては、コンクリートの破壊特性、試験機の特性

(剛性、秤量、レンジ、球座、載荷板等)、試験方法あるいは供試 休の整形といった要因が密接に関係しており、その結果、压縮強度 の確率分布形状が異なるものと考えられる。特に、強度特性は構造 敏感性を示すといわれており、宫強度となるほど微細な欠陥が強度 に大きな影響を及ほすと考えられる。しかし、現段階においてはそ の要因の特定は難しく、今後、要因を抽出して特定する必要がある といえる。また、強度レベルが $60 \mathrm{~N} / \mathrm{mm}^{2}$ クラスであっても強度レベ ルが $100 \mathrm{~N} / \mathrm{mm}^{2}$ クラスの分布形状を示す場合もあり（図ー 3 の A 社 の例）、これらの相違についても要因を特定する必要があり、今後 の課題と考えている。

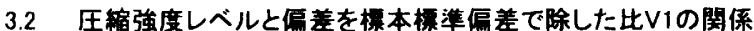

図ー3に各強度レベル別に偏差（ $\Delta X ）$ を標本標準偏差で除し た比（V1）の分布を示す。各強度レベルと偏差を標本標準偏差で 除した比から各試験值が平均值に対して分布する可能性の傾向が示 されているが、これによると偏差の分布同様に、強度レベルが 60 $\mathrm{N} / \mathrm{mm}^{2}$ までは正規分布を示すことが確認されたが、強度レベルが80 $\mathrm{N} / \mathrm{mm}^{2}$ 以 にになると正規分布の形状とは買なる形状を示すことが碓 認された。特に強度レベルが $100 \mathrm{~N} / \mathrm{mm}^{2} に$ にいては最頻值が平均值 より帛い侧（十側）に移行し、平均値よりも鬲い強度となる確率が 人きくなる一クで、平均值よりも人幅に強度がト问る叮能性がある ことも示唆する分布形状となっていることが明らかとなった。

\section{3 圧縮强度レベルと確车分布形状について}

前報”および本解析結果より各強度レベルにおける偏差（ $\Delta \mathrm{X} ）$ 及び偏差を標本標隻偏差で除した比 $(\Delta \mathrm{V})$ の頻度分布を求めたと ころ、図ー4に示すような压敉強度分布の倾向を示すことが示唆さ
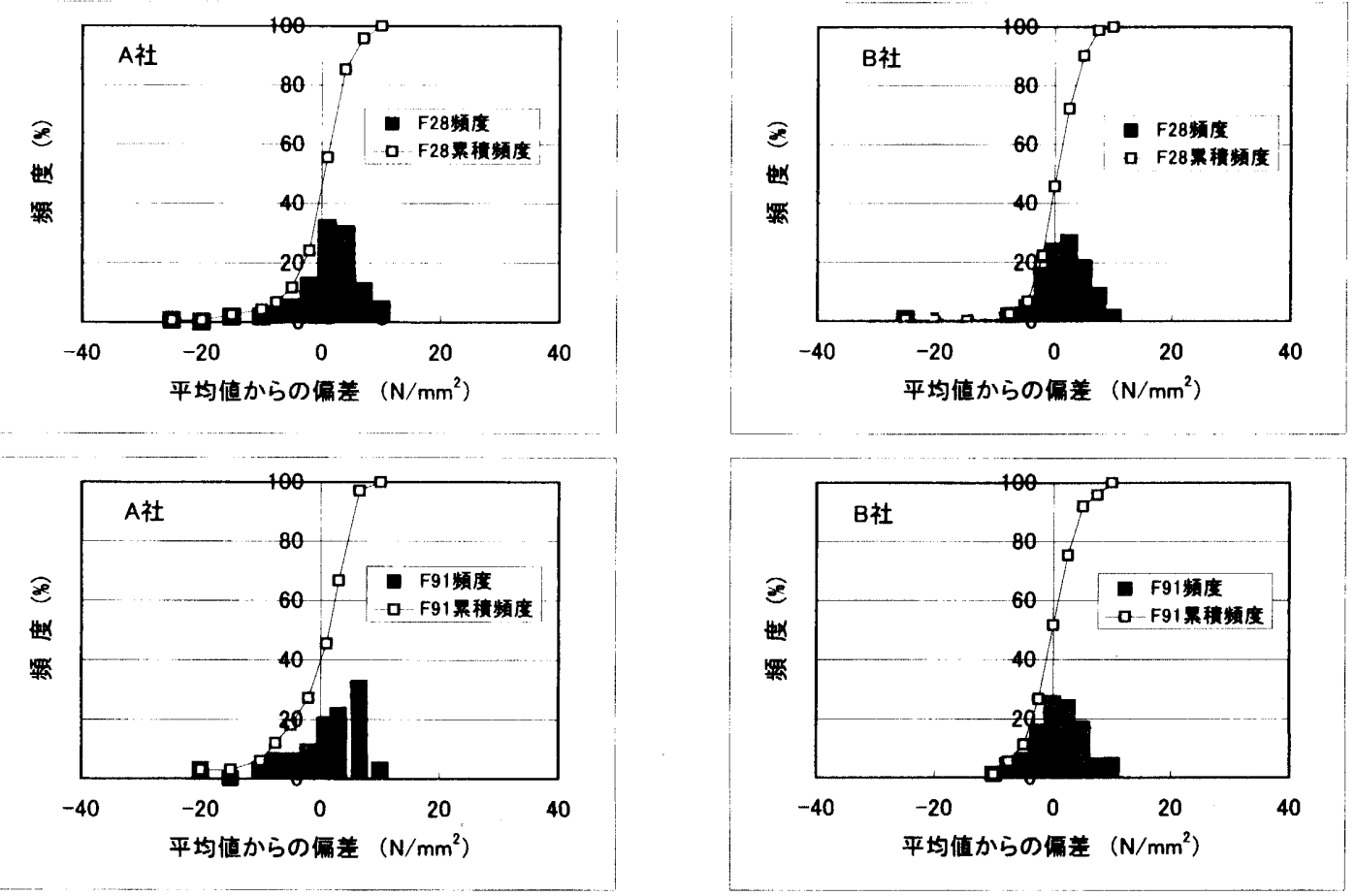

注)F28: 材峆28日, F91: 材秢91日を表す。

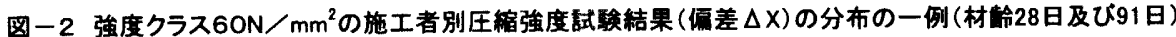



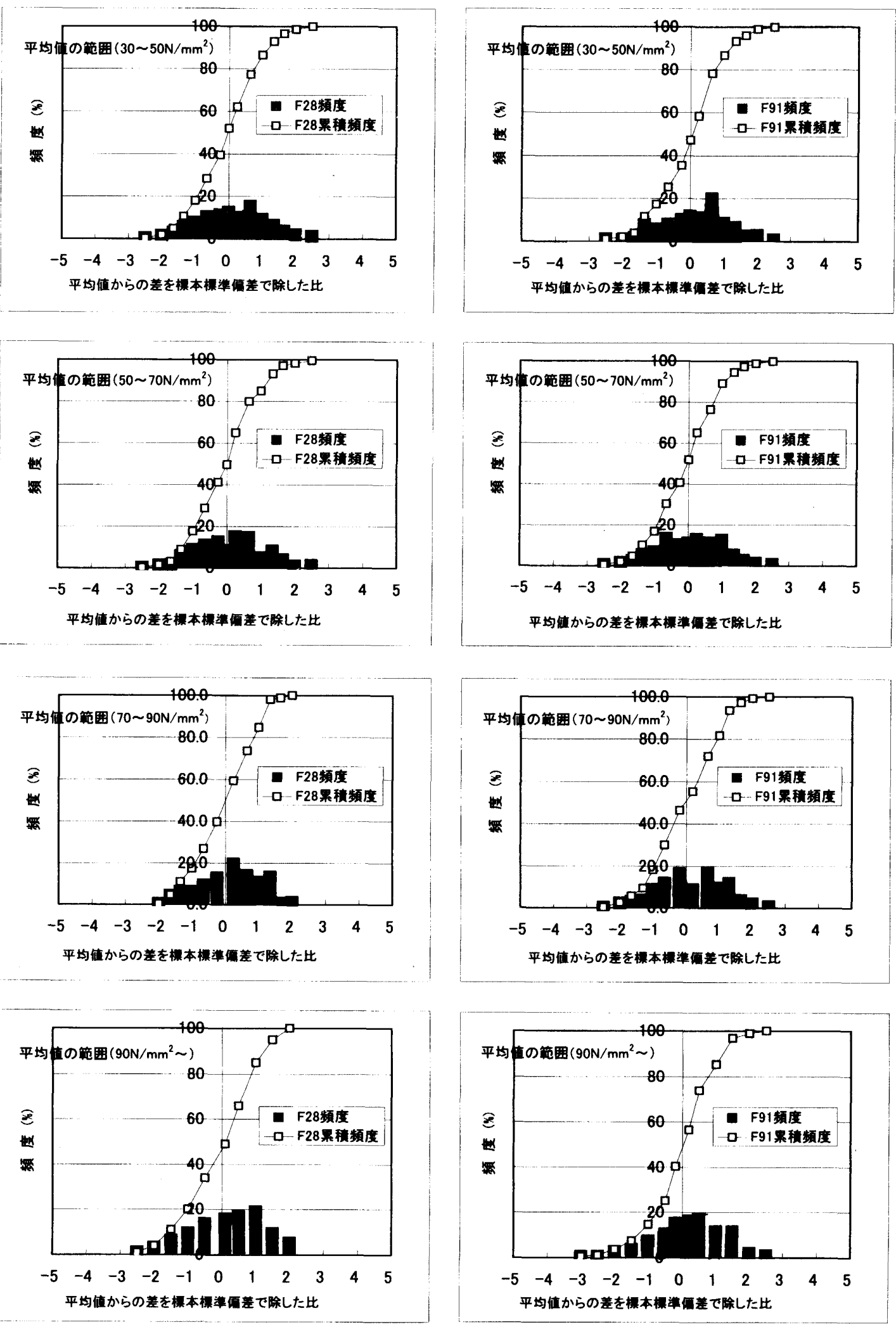

注)F28; 材铪28日，F91：材粭91日を表す。

図ー3 コア供試体の圧縮強度(材秢28日及び91日)の平均值からの差を標本標準偏差で除した比の分布 


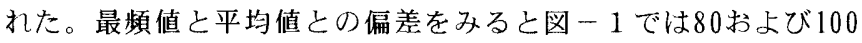
$\mathrm{N} / \mathrm{mm}^{2}$ クラスで3〜 $5 \mathrm{~N} / \mathrm{mm}^{2}$ 、最頻値が平均值より大きくなる傾向を 示している。また、図ー3においては同クラスの標準偏差が0. 5〜 $1 \sigma$ 程度、強度が高い側に移行することが確認された。この結果、 垷行の JIS A 1108 （コンクリートの圧縮強度試験方法）に従い、鋼 製の型枠を用いて作製したコンクリート供試体あるいは構造体コン クリートから採取したコア供試体で圧縮強度試験を行った場合、強 度レベルが高いコンクリートになると、その試験結果は必ずしも正 規分布にならない可能性があることが明らかとなった。現行の品質 管理においては、いずれの強度レベルにおいても压縮強度の試験結 果が正規分布を示すと仮定して調合（配合）設計ならびに品質管理 が行われているため、平均值を中央値として設計、管理を行った場 合には、管理規準からはずれる（不合格）試料が発生する可能性が あることを示唆するものである。これは、こ扒らの強度レベルのコ ンクリートではJASS50設計基準に基づく方法あるいはレディーミ クストコンクリートの管理規準に基づく方法では所定の品質を確保 できない確率が発生することとなるため、管理手法や設計基準、管 埋規準等の見直しが必要と考えら扎る。

\section{4. 結論}

棈造体コンクリートから採取したコア供試体の压縮強度における 確率分布を検討した結果、本研究の範囲内で以下のことが明らかに なった。

（1）構造体コンクリートから採取したコア供試体の強度レベルが60 $\mathrm{N} / \mathrm{mm}^{2}$ (圧縮强度の平均值が50 70 $/ \mathrm{mm}^{2}$ ) 未では㴼強度の平均値 からの偏差の分布は、ほぼ正規分布を示すことが確認されした。

(2) 構造体コンクリートから採取したコア供試体の強度レベルが80

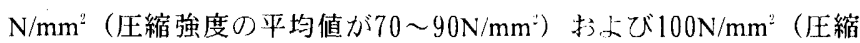
強度の平均值が $90 \mathrm{~N} / \mathrm{mm}^{2}$ 以上）の王縮強度の平均値からの偏差の分 布は正規分布を示さず、強度レベルが高くなるほど圧縮強度分布に おける最頻值が最大值側に移行し、分布のすそのが広がる形状を示 すことが確認された。また、強度レベルが高くなるほど、分布領域 の幅が広がる形状となった。

（3）コア供試体の压縮強度の偏差を標本標準偏差で除した比の分布 については、偏差の分布と同样に強度レベルが $60 \mathrm{~N} / \mathrm{mm}^{2}$ までは正規 分布上なるが、強度レベルが $80 \mathrm{~N} / \mathrm{mm}$ 以上になる上正規分布の形状 とは異なる形状を示すことが確認さ扎た。特に強度レベルが 100 $\mathrm{N} / \mathrm{mm}^{2}$ においては頻度が平均值より高い側（十側）に移行し、平均 值よりも高い強度が出現する確率が大きくなる・方で、平均值より も大幅に低い強度が出現する確率も大きくなることが示唆された。 （4）圧縮強度レベルが高いコンクリートになると、その試験結果は 必ずしも正規分布しない可能性があり、現行の品質管理において は、いずれの強度レベルにおいても压縮強度の試験結果が正規分布 すると仮定して設計ならびに品質管理が行われているため、平均值 を中央値として設計、管理を行った場合には、管理規準からはずれ る(不合格) 試料が発生する可能性が生じる。このような分布を示 す強度レベルのコンクリートではJASS5の設計基準に基づく方法あ るいはレディーミクストコンクリートの管理規準に基づく方法では 所定の品質を確保できない確率が生じることとなるため、管理手法
あるいは基・規準等の見直しが必要と考えられる。

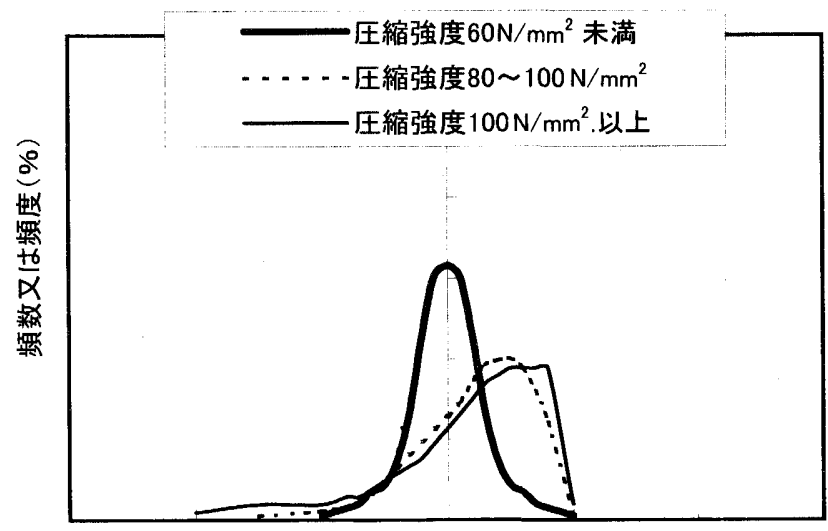

圧縮強度 $\left(\mathrm{N} / \mathrm{mm}^{2}\right)$

図-4 圧縮強度の分布の概念

\section{参考文献}

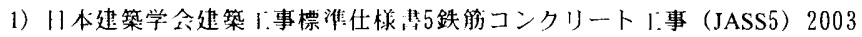

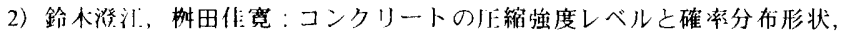

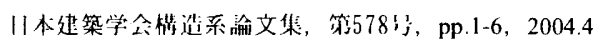

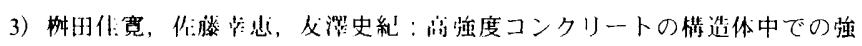

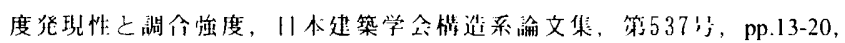
2000.11

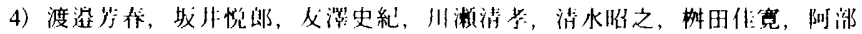

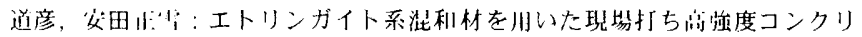

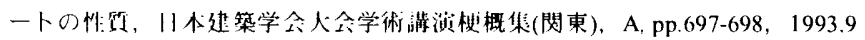

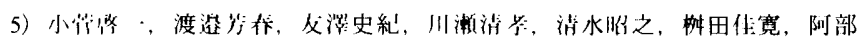

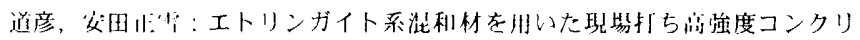

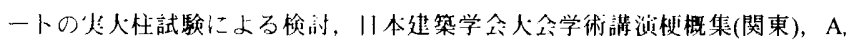
pp.699-700, 1993.9

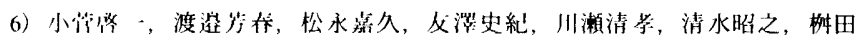

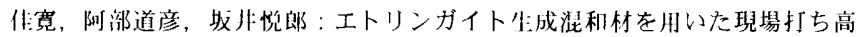
饳度コンクリートの性:颔, 11 本建築学会大会学術講演梗概集(東海), $\mathrm{A}$, pp.249-250, 1994.9

7）荒川総一郎, 友澤史糺, 桝田佳寞, 消水昭之, 阿初道彦, 野川貴文: 高 強度コンクリートの建朋化に関する研究その 1 全体計剽，日本建築学会大 会学術講演梗概集(近畿)，A-1，pp.203-204，1996.9

8）哭 相均，发澤史紀，荒川総一郎，大村陳庭：高強度コンクリートの䒠 朋化に関守る研究その 2 フレッシュコンクリートの性質, 日本建築学会大 会学術講演梗概集(近狨)，A-1，pp.205-206，1996.9

9）传野 寛, 桝田佳宽, 古川雄二, 山本幸雄：高強度コンクリートの尖用

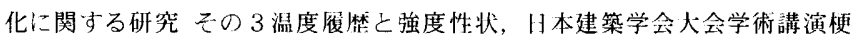
概集(近畿), A-1, pp.207-208, 1996.9

10) 金森誠治, 渡部 聡, 櫻牛重英: 高強度コンクリートの垁大施 $\mathrm{I}$ 実験 (そ の1，その2)，日本建築学会大会学術講演梗概集(九州)，A-1，pp.833-836，1998.9 11）和田利之，桝田使寛，中村成春，上西 隆，河野政典，起橋莩徳：100 $\mathrm{N} / \mathrm{mm}^{2}$ 級高強度コンクリートを用いた構造体の強度特性及び発生忑力（その 1, その2)，日本建築学会大会学術講演梗概集(中国)，A-1, pp.21-24, 1999.9

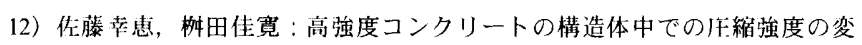
動，日本建築学会構造系論文集，第562号，pp.9-14，2002.12 